\title{
PEMBERIAN SERTA PENGAWASAN KREDIT PADA PT. BANK PERKREDITAN RAKYAT JORONG KAMPUNG TANGAH PARIAMAN
}

\author{
Nofi Wahyuni, Mariani St.B Tanjung \\ Akademi Keuangan dan Perbankan Padang \\ mstbtanjung@gmail.com
}

\begin{abstract}
ABSTRAK
Penelitian ini bertujuan untuk mengetahui 1) Bagaimana perusahaan menerapkan pemberian serta pengawasan kredit guna keefektifan kegiatan dalam operasional perusahaan, 2) Apakah pemberian serta pengawasan kredit yang diterapkan dapat meningkatkan efisiensi pada PT. BPR Jorong Kampung Tangah Pariaman. Dalam menganalisa data, penulis menggunakan metode analisa data kualitatif. Didalam pemberian kredit PT. BPR Jorong Kampung Tangah Pariaman disalurkan melalui nasabah/debitur yang masih produktif dalam arti kata masih berpenghasilan yang tujuannya agar nasabah dapat membayar kembali kredit yang telah diberikan sesuai dengan syarat-syarat yang telah ditetapkan antara pihak bank dengan nasabah / debitur.
\end{abstract}

Kata Kunci: Pengawasan Kredit

\section{PENDAHULUAN}

Perbankan mempunyai tugas yang sangat penting dalam rangka mendorong pencapaian tujuan nasional yang berkaitan dalam peningkatan dan pemerataan taraf hidup masyarakat dan peningkatan kelangsungan perekonomian Indonesia. Pertumbuhan ekonomi harus diarahkan untuk meningkatkan pendapatan masyarakat serta mengatasi ketimpangan ekonomi dengan kesenjangan sosial. Pertumbuhan ekonomi guna meningkatkan pendapatan masyarakat, perlu diberikan perhatian bagi usahausaha untuk membina dan melindungi usaha kecil dan tradisional serta golongan ekonomi lemah. Hal ini bukan hanya dalam meningkatkan produksi saja tetapi juga untuk mencegah melebarnya jurang pemisah antara kaya dan miskin sehingga tercipta masyarakat yang adil dan makmur, sesuai dengan tujuan pembangunan di Indonesia.

Definisi bank yang dapat diberlakukan di Negara kita adalah sesuai dengan aturan yang ada yaitu tercantum dalam undang-undang Republik Indonesia Nomor 10 Tahun 1998 tentang perbankan dan merupakan perubahan atas undang-undang Nomor 7 Tahun 1992. Pengertian bank memberi tekanan bahwa bank dalam mengajukan usahanya terutama menghimpun dana dalam bentuk simpanan yang merupakan sumber dana 
bank, kegiatan bank juga harus pula diarahkan pada peningkatan taraf hidup rakyat banyak. Peranan bank dalam mendukung kegiatan perekonomian cukup besar karena bank memberikan jasa dalam lalu lintas peredaran uang. Dilihat dari fungsi utama sebuah Bank adalah sebagai lembaga yang dalam aktivitas usahanya menghimpun dan menyalurkan dana masyarakat. Salah satu cara penyaluran dana tersebut adalah melalui kebijakan kredit yang dilakukannya, sehingga dengan kata lain kesehatan perbankan akan sangat dipengaruhi oleh resiko kredit. Pengelolaan resiko kredit yang tidak efektif yang antara lain disebabkan kelemahan dalam penerapan serta pengawasan kebijakan dan prosedur pemberian kredit, dan penilaian kemampuan debitur dalam menyelesaikan kredit. Ditinjau dari sudut pandang bank, kredit mempunyai suatu kedudukan yang strategis dimana sebagai salah satu sumber uang yang perlu dalam membiayai kegiatan usaha yang dapat dititik beratkan sebagai kunci kehidupan bagi setiap manusia.

Sistem pengawasan kredit akan dilakukan dalam menjamin kepentingan bank terhadap kredit yang diberikan, maka bank menerapkan sistem pengawasan pemberian kredit yang diawali dengan prosedur permohonan kredit, pengawasan lanjutan setelah kredit diterima debitur sampai dengan prosedur pelunasan kredit oleh debitur. Di dalam proses pengawasan sebelum pemberian kredit pada debitur, bank meminta laporanlaporan yang diperlukan secara periodik tentang perkembangan usahanya khususnya tentang usaha yang dibiayai oleh bank sehingga bank dapat mengawasi usaha nasabahnya. Pengawasan kredit yang diberikan oleh bank sangat penting artinya bagi bank untuk menjamin kepentingannya terhadap pembayaran kembali kreditnya dan untuk memastikan digunakan sesuai rencana permohonan kredit.

Kredit merupakan salah satu bagian pembentukan modal yang dilakukan oleh lembaga keuangan dalam hal ini pihak perbankan ke masyarakat dalam upaya mendorong kinerja usaha sehingga dapat dimanfaatkan untuk meningkatkan produktivitas usaha sektor riil yang dilakukan oleh masyarakat secara individu maupun kelompok.

Pengertian kutipan pemberian kredit menurut UU No. 10 Tahun 1998 tentang Perbankan : Kredit adalah Penyediaan dan atau tagihan yang dapat dipersamakan dengan itu, berdasarkan persetujuan atau kesepakatan pinjam meminjam antara bank dengan pihak lain yang mewajibkan pihak meminjam untuk melunasi hutangnya setelah jangka waktu tertentu dengan pemberian bunga.

Dari pengertian diatas dapat disimpulkan bahwa antara Bank dan Kredit mempunyai kaitan yang erat. Pada PT. BPR Jorong Kampung Tangah Pariaman adalah salah satu dari beberapa bank yang usaha pokoknya sebagai penghimpun dana dari masyarakat dan memberikan pinjaman kepada masyarakat yang diberikan dalam bentuk kredit agar terciptanya kondisi perekonomian yang lebih sempurna.

Berdasarkan latar belakang penelitian yang telah dikemukakan diatas, maka penulis mencoba menyimpulkan rumusan masalah yang dapat mengarahkan penyelesaian penelitian ini, yaitu : 
1. Bagaimana perusahaan menerapkan pemberian serta pengawasan kredit guna keefektifan kegiatan dalam operasional perusahaan.

2. Apakah pemberian serta pengawasan kredit yang diterapkan dapat meningkatkan efisiensi pada PT. BPR Jorong Kampung Tangah Pariaman.

\section{LANDASAN TEORI}

\section{Pengertian dan Jenis-jenis Kredit}

Menurut Johanes (2004:7) kata "kredit" berasal dari bahasa Romawi "credere" yang berarti percaya atau credo atau creditum yang berarti saya percaya. Dengan demikian dasar dari pada kredit adalah kepercayaan.

Dilihat dari sudut ekonomi, kredit diartikan sebagai penundaan pembayaran. Maksudnya pengembalian atas penerimaan uang dan / atau suatu barang tidak dilakukan bersamaan pada saat penerimaannya, akan tetapi pengembaliannya dilakukan pada masa tertentu yang akan datang.

Undang-undang perbankan nomor 10 tahun 1998 menyebutkan pengertian kredit, Kredit adalah penyediaan uang atau tagihan yang dapat di persamakan dengan itu, berdasarkan persetujuan atau kesepakatan pinjam meminjam antara bank dengan pihak lain yang mewajibkan pihak peminjam untuk melunasi utangnya setelah jangka waktu tertentu dengan pemberian bunga, imbalan atau pembagian hasil tertentu. Kredit juga didefinisikan sebagai penyerahan atas dasar kepercayaan sejumlah uang atau barang yang dipersamakan dan wajib dikembalikan sesuai dengan syarat-syarat yang disepakati bersama.

Adapun menurut Hasibuan (2007:87) mengemukakan pengertian kredit yang lebih jelas bahwa: " Kredit adalah penyediaan uang atau tagihan yang harus dibayar kembali bersama bunganya oleh peminjam sesuai dengan perjanjian yang telah disepakati".

Selanjutnya Latumerissa (1999:45) kredit adalah : "Penyerahan sesuatu yang mempunyai nilai ekonomis pada saat sekarang ini atas dasar kepercayaan, sebagai pengganti sesuatu yang mempunyai nilai ekonomis yang sepadan dihari kemudian.

Kemudian Suyatni, (2002:12) memberikan definisi kredit sebagai berikut: Kredit dapat pula berarti bahwa pihak kesatu memberikan prestasi baik berupa barang, uang atau jasa kepada pihak lain, sedangkan kontra prestasi akan diterima kemudian dalam jangka waktu tertentu".

Berdasarkan pengertian diatas nampak bahwa suatu fungsi pokok dari kredit pada dasarnya adalah untuk pemenuhan jasa pelayanan terhadap kebutuhan masyarakat dalam rangka mendorong dan melancarkan kegiatan usaha berbagai bidang yang semua itu untuk meningkatkan taraf hidup rakyat dalam hal ini mempermudah dan mempercepat mendapatkan modal usaha.

Untuk menentukan berkualitas atau tidaknya suatu kredit perlu diberikan ukuran - ukuran tertentu. Bank Indonesia menggolongkan kualitas kredit menurut ketentuan yang berlaku. Secara umum jenis-jenis 
kredit yang dikeluarkan oleh bank dapat dilihat dari berbagai segi jenisjenis kredit, adalah:

1. Dari Segi Jangka Waktu

Pemakaian kredit menurut jangka waktu berdasarkan lamanya pemakaian suatu kredit ditentukan oleh kebutuhan dan kemampuan nasabah untuk memakai dan mengembalikannya pada suatu waktu tertentu. Penggolongan kredit atas jangka waktu pemakaiannya adalah sebagai berikut.

a. Kredit jangka pendek

Merupakan kredit yang memiliki jangka waktu kurang dari satu tahun atau paling lama satu tahun dan biasanya untuk keperluan modal kerja. Contohnya untuk peternakan misalnya kredit peternakan ayam atau jika untuk pertanian misalnya tanaman padi dan palawija.

b. Kredit jangka menengah

Jangka waktu kreditnya berkisar antara satu tahun sampai tiga tahun, dan biasanya kredit ini untuk melakukan investasi.

c. Kredit jangka panjang

Merupakan kredit yang masa pengembaliannya paling lama, yaitu diatas tiga tahun atau lima tahun dan biasanya untuk keperluan investasi jangka panjang.

2. Dari Segi Tujuan Dan Kegunaannya

a. Kredit investasi

Kredit yang biasanya untuk perluasan usaha atau untuk keperluan penanaman modal, dimana masa pemakaiannya untuk satu periode yang relatif lebih lama dan biasanya kegunaan kredit ini adalah untuk kegiatan utama suatu perusahaan. Misalnya untuk membangun pabrik, gudang, membeli / mengganti mesin-mesin dan lain sebagainya.

b. Kredit modal kerja

Merupakan kredit yang dipergunakan untuk keperluan meningkatkan produksi dalam operasionalnya. Kredit modal kerja merupakan kredit yang dicairkan untuk mendukung kredit investasi yang sudah ada.

c. Kredit konsumtif

Merupakan kredit yang dipergunakan untuk konsumsi secara pribadi, misalnya untuk perumahan, kredit mobil dan lain sebagainya.

3. Dari Segi Jaminan

a. Kredit dengan jaminan

Merupakan kredit yang diberikan dengan suatu jaminan tertentu artinya setiap kredit yang dikeluarkan akan dilindungi oleh jaminan yang diberikan debitur. Kredit dengan jaminan ini merupakan penilainnya yang lengkap, dalam arti segala aspek penilaian turut dipertimbangkan termasuk collateral. Mengenai jaminan kreditnya dapat berupa tanah, rumah, pabrik dan atau mesin-mesin serta 
barang-barang bergerak lainnya. Jenis kredit ini lazim dipakai oleh seluruh bank di Indonesia.

b. Kredit tanpa jaminan

Yaitu kredit yang diberikan tanpa jaminan ataupun orang tertentu. Hanya melihat prospek usaha, karakter serta loyalitas sicalon debitur selama berhubungan dengan yang bersangkutan. Namun di Indonesia kredit tanpa jaminan ini menurut Undang-undang Nomor 14/1967 dilarang untuk diberikan oleh bank-bank (Pasal 24 ayat (1)).

\section{Perencanaan Pemberian Kredit}

Dalam perencanaan pemberian kredit PT. BPR Jorong Kampung Tangah Pariaman terlebih dahulu memperhatikan apa saja yang termasuk didalam prosedur pemberian kredit sebelum kredit tersebut diberikan. Jenis-jenis kredit yang ditawarkan di PT. Bank Perkreditan Rakyat Jorong Kampung Tangah Pariaman yaitu :

1. Kredit Instalment

Kredit yang pembayaran cicilannya angsuran pokok ditambah angsuran bunga dimana bunga yang diberikan dengan sistem flat / tetap.

2. Kredit Reguler

Kredit yang pembayaran cicilannya angsuran bunga dibayar terlebih dahulu dengan menggunakan sistem sliding, sementara angsuran pokoknya dibayar setelah jatuh tempo pembayarannya.

Prosedur pemberian dan penilaian kredit oleh dunia perbankan secara umum antar BPR yang satu dengan BPR yang lain tidak jauh berbeda. Yang menjadi perbedaan mungkin hanya terletak dari bagaimana tujuan BPR tersebut, serta persyaratan yang ditetapkannya dengan pertimbangan masing-masing. Secara umum prosedur pemberian kredit oleh BPR adalah sebagai berikut :

1. Calon debitur mengajukan permohonan kredit secara tertulis ke bank yang dituju.

2. Calon debitur mengisi daftar isian / formulir yang telah disediakan oleh bank, dengan melampirkan :

Jika jaminan BPKB

a. Foto copy KTP suami dan istri (3 lembar)

b. Foto copy kartu susunan keluarga (3 lembar)

c. Foto copy STNK (3 lembar)

d. Foto copy BPKB (3 lembar)

e. Foto copy buku KIR (untuk roda 4 jenis angkutan)

f. Kendaraan jaminan dan data asli harus dibawa

Jika jaminan sertifikat tanah

a. Foto copy KTP suami dan istri (3 lembar)

b. Foto copy kartu susunan keluarga (3 lembar)

c. Foto copy sertifikat tanah (2 lembar)

d. Bukti pembayaran pajak tanah dan bangunan (SPPT)

e. Sertifikat aslinya harus dibawa 
3. Bank meneliti surat permohonan/aplikasi kredit serta kelengkapan dan kebenaran dokumen-dokumen yang diserahkan calon debitur.

4. Bank melakukan penelitian / menganalisa terhadap dana yang tersedia (plafond kredit) dan pribadi calon nasabah serta segala sesuatu yang disyaratkan, yang berhubungan dengan usaha calon nasabah yang menyangkut :

a. Faktor 5C Nasabah.

1) Character ( Kepribadian, watak )

Hal-hal yang harus diperhatikan sehubungan dengan character ini adalah sifat pribadi yang meliputi perilaku sehari-hari atas diri calon debitur, cara hidup, keadaan keluarga, hobby, pergaulannya dalam masyarakat, riwayat hidup dan lain sebagainya. Hal-hal tersebut merupakan suatu ukuran tentang kemauan untuk membayar. Orang yang memiliki karakter yang baik akan berusaha untuk membayar kreditnya dengan berbagai cara.

2) Capacity ( Kemampuan, kesanggupan)

Capacity adalah kemampuan calon debitur dalam mengembangkan dan mengendalikan usahanya serta kesanggupannya dalam menggunakan fasilitas kredit yang diberikan.

3) Capital (Modal, kekayaan)

Yang dimaksud dengan capital adalah modal usaha dari calon nasabah yang telah tersedia/telah ada sebelum mendapatkan fasilitas kredit. Keadaan, struktur dan sifat permodalan tersebut akan menentukan seberapa besar fasilitas kredit bank yang akan diberikan sebagai tambahan modal.

4) Collateral (Jaminan, agunan)

Collateral merupakan jaminan yang diberikan oleh calon nasabah. Jaminan ini bersifat sebagai jaminan tambahan, karena jaminan utama kredit adalah pribadi calon nasabah dan usaha.

5) Condition of economy

Kondisi ekonomi yang perlu diperhatikan sehubungan dengan permohonan kredit, tidak saja kondisi ekonomi pada sector usaha calon debitur tetapi juga kondisi ekonomi secara umum dimana perusahaan calon debitur itu berada. Kondisi perekonomian akan mempengaruhi kegiatan dan prospek usaha peminjam, dalam rangka proyeksi pemberian kredit, kondisi perekonomian harus pula dianalisis (paling sedikit selama jangka waktu kredit).

Namun pada kondisi penganalisaan terhadap factor 5C tersebut diterapkan, pihak PT. BPR Jorong Kampung Tangah pada prakteknya dilapangan juga menerapkan penganalisaan menurut Gup dan Kolari $(2005 ; 263)$ tersebut adalah analisa Compliance yaitu kepatuhan terhadap hukum dan undang-undang yang berlaku itu sangatlah penting. Hal ini menyangkut atas 
kepatuhan kreditur dan debitur dengan perjanjian yang telah disepakati bersama. Nasabah tidak pernah memiliki catatan kriminal dalam kepolisian. Nasabah juga mematuhi peraturan yang ada di bank, yaitu memenuhi persyaratan permohonan kredit dengan lengkap.

b. Tujuan penggunaan kredit.

c. Plafon, jangka waktu dan jenis kredit diajukan.

d. Masa tenggang khususnya pada kredit investasi.

e. Cara pembayaran.

f. Sumber pelunasan kredit.

g. Analisa jaminan kredit dan pengikatannya.

h. Penetapan biaya adm, divisi, komisi dan asuransi kredit.

i. Persetujuan kredit yang berbeda dalam rekomendasi, harus jelas alasannya.

5. Keputusan kredit

Setelah proses analisis tersebut sudah dilaksanakan, maka petugas kredit dapat memutuskan, apakah kredit tersebut disetujui, ditolak, dikurangi, ditambah atapun diperpanjang.

6. Bank menyuruh debitur untuk menandatangani Akad Perjanjian Kredit (APK) dengan membawa aplikasi dokumen kredit.

7. Penandatanganan APK

a. Notaris

b. Pegawai

8. Pencairan kredit

a. Debitur dapat membuka rekening tabungan pada bank.

b. Debitur membuat surat kuasa kepada bank untuk melakukan pendebetan rekening.

c. Bagian Adm kredit memo pencairan kredit, bagian tabungan beserta kwitansi pencairan kredit rangkap dua, nota kredit atas pencairan kredit, nota debet untuk pembebanan biaya adm, provisi dan komisi, materai notaris dan asuransi.

d. Debitur menandatangani kwitansi pencairan kredit dihadapan petugas tabungan.

e. Kertas asli diserahkan kebagian adm kredit, lembar tembusan diserahkan kepada tembusan.

Permohonan kredit yang tidak disetujui.

Membuat surat penolakan atas permohonan kredit kepada calon debitur yang mencatumkan alasan-alasan penolakan dan mengembalikan seluruh dokumen calon debitur yang diserahkan pada saat pengajuan kredit.

\section{Pelaksanaan Pemberian Kredit}

Permohonan kredit dapat dicairkan jika, didalam permohonan kredit secara tertulis telah memenuhi keabsahan dan persyaratan hukum yang dapat melindungi kepentingan bank, baik yang memuat besarnya kredit, jangka waktu kredit, suku bunga kredit, dan tata cara dan syarat pencairan, tata cara pembayaran kembali. 
Kredit dapat dicairkan jika permohonan kredit telah ditanda tangani, pengikatan jaminan telah dilakukan, debitur telah melunasi biaya-biaya dan seluruh aspek yuridis telah memberikan perlindungan yang memadai, bagi bank.

Adanya aturan hukum mengenai pelaksanaan pembebanan Hak Tanggungan dalam suatu perjanjian kredit bertujuan untuk memberikan kepastian dan perlindungan hukum bagi semua pihak dalam memanfaatkan tanah beserta benda-benda yang berkaitan dengan tanah sebagai jaminan kredit. Untuk itu, praktik pengikatan kredit dengan jaminan Hak Tanggungan dalam kegiatan perbankan hendaknya dapat dilaksanakan sesuai yang telah diatur dalam Undang- Undang Hak Tanggungan (UUHT).

Setiap pemberian kredit harus dibuatkan suatu perjanjian tertulis antara bank dengan sipemohon kredit. Pemberian kredit tanpa perjanjian tertulis tidak dibenarkan oleh pemerintah.

Dalam perjanjian kredit harus tertera beberapa hal diantaranya :

1. Jumlah kredit yang diberikan.

2. Jangka waktu kredit yang telah disepakati.

3. Keperluan kredit.

Keperluan kredit harus sesuai dengan bidang usaha debitur, berdasarkan target produktifitas yang akan dicapainya. Adapun pemberian kredit pada PT. BPR Jorong Kampung Tangah digunakan untuk membiayai usaha debitur dalam segi penggunaannya dan sektor ekonomi.

4. Bunga kredit.

Ketentuan bunga pada PT. BPR Jorong Kampung Tangah Pariaman.

a. Cara perhitungan

1) Bunga flat yaitu bunga yang didasarkan pada limit kredit selama jangka waktu kredit.

2) Bunga anuitas yaitu perhitungan yang didasarkan pada bukti debet harian dan besarnya angsuran/ bulan ( pokok dan bunga )

3) Bunga efektif yaitu perhitungan bunga yang didasarkan pada bukti debet harian dikalikan dengan bunga yang berlaku.

b. Hari bunga

Hari bunga kredit dihitung 30 hari dalam sebulan / 360 hari dalam setahun.

c. Waktu pembebanan

Pembebanan bunga disesuaikan dengan tanggal jatuh tempo angsuran sebagaimana yang diperjanjikan dalam surat keputusan.

d. Jenis bunga

1. Fixed rate yaitu suku bunga yang dikenakan secara tetap selama jangka waktu kredit.

2. Floating rate yaitu suku bunga yang dikenakan secara mengambang artinya sewaktu-waktu dapat berubah sesuai perkembangan bunga yang berlaku dipasaran.

\section{Perkembangan Jumlah Kredit Yang Diberikan}

Dalam kegiatan perkreditan bank, khususnya PT. BPR Jorong Kampung Tangah memberikan kredit kepada debitur. Pengembalian ini 
sering disebut sesuai dengan sektor usaha debitur. Adapun kredit yang diberikan oleh PT. BPR Jorong Kampung Tangah berdasarkan jenis penggunaan yang digunakan untuk keperluan penambahan modal, investasi dan konsumsi sedangkan pemberian kredit berdasarkan sektor ekonomi digunakan untuk keperluan pertanian, perindustrian, perdagangan, dan jasa-jasa.

Hal ini dapat digambarkan pada tabel dibawah ini selama tiga tahun terakhir yang dimulai pada tahun 2009 sampai tahun 2011.

\section{Tabel 1}

Penyaluran Kredit Berdasarkan Penggunaan

( dalam ribuan rupiah)

\begin{tabular}{|l|l|r|r|r|}
\hline \multirow{2}{*}{ No } & \multicolumn{1}{|c|}{ Uraian } & \multicolumn{3}{|c|}{ 31 Desember } \\
\cline { 3 - 5 } & & 2009 & \multicolumn{1}{c|}{2010} & \multicolumn{1}{c|}{2011} \\
\hline & Penggunaan & 7.130 .891 & 7.415 .416 & 9.199 .287 \\
1. & Modal Kerja & 849.012 & 485.520 & 493.149 \\
2. & Investasi & 922.232 & 1.232 .514 & 1.617 .360 \\
3. & Konsumsi & 8.902 .135 & 9.133 .450 & 11.309 .796 \\
\hline
\end{tabular}

Sumber : PT. BPR Jorong Kampung Tangah Pariaman

Tabel 2

Penyaluran Kredit Berdasarkan Sektor Ekonomi

( dalam ribuan rupiah )

\begin{tabular}{|l|l|r|r|r|}
\hline \multirow{2}{*}{ No } & \multicolumn{1}{|c|}{ Uraian } & \multicolumn{3}{|c|}{ 31 Desember } \\
\cline { 3 - 5 } & & 2009 & \multicolumn{1}{c|}{2010} & \multicolumn{1}{c|}{2011} \\
\hline & Sektor Ekonomi & & & \\
1. & Pertanian & 419.821 & 547.407 & 1.174 .142 \\
2. & Perindustrian & 734.222 & 975.409 & 803.727 \\
3. & Perdagangan & 4.463 .213 & 5.598 .894 & 6.995 .685 \\
4. & Jasa-jasa & 2.362 .647 & 779.226 & 741.512 \\
\hline \multicolumn{2}{|l|}{ Total Kredit } & 7.979 .903 & 7.900 .936 & 9.715 .066 \\
\hline
\end{tabular}

Sumber : PT. BPR Jorong Kampung Tangah Pariaman

Dalam perkembangan kredit pada PT. BPR Jorong Kampung Tangah Pariaman mengalami perkembangan hal ini dapat dilihat pada total kredit berdasarkan penggunaan pada tahun 2009 sebesar 8.902.135 menjadi 9.133.450 pada tahun 2010, yaitu mengalami kenaikan sebesar 231.315, dan 9.133.450 pada tahun 2010 menjadi 11.309 .796 pada tahun 2011. Jadi kenaikannya sebesar 2.176.346.

Perkembangan total kredit tidak diikuti dengan penurunan kredit pada sektor ekonomi yang dapat dilihat pada tahun 2009 sebesar 7.979.903 menjadi sebesar 7.900 .936 pada tahun 2010, yaitu mengalami penurunan sebesar 78.967, namun 7.900.936 pada tahun 2010 menjadi 9.715 .066 pada tahun 2011 mengalami kenaikan sebesar 1.814.130.

Penurunan total kredit pada sektor ekonomi dipicu oleh penurunan jumlah pemberian kredit pada sektor jasa yang mengalami penurunan yang dilihat pada tahun 2009 sebesar 2.362.647 menjadi 779.226 pada tahun 2010 yang mengalami penurunan sebesar 1.583.421. Hal ini dipicu oleh kurangnya keinginan masyarakat atau nasabah untuk membuka usaha 
dalam bidang jasa karena masyarakat sekitar lebih cenderung melakukan penjualan ataupun perdagangan, hal ini dapat dilihat dari masyarakat pariaman lebih banyak berjualan yang dianggap lebih banyak mendapatkan keuntungan.

Penurunan tingkat pemberian kredit pada sektor jasa ini juga diikuti pada sektor perindustrian pada tahun 2010 sebesar 975.409 menjadi 803.727 pada tahun 2011, yaitu mengalami penurunan sebesar 171.682. Hal ini dipicu oleh beberapa faktor :

a. Kurang kondusifnya lingkungan usaha yang berpengaruh bagi sektor industri sebagai lapangan kesempatan kerja utama.

b. Buruknya kualitas kelembagaan publik yang menjalankan fungsinya sebagai fasilitator dan pusat pelayanan

c. Rendahnya efisiensi usaha pada tingkat operasional perusahaan.

d. Lemahnya iklim persaingan usaha.

Jadi dapat disimpulkan pada pemberian kredit berdasarkan penggunaan merupakan perkembangan jumlah kredit yang mengalami kenaikan dari pada pemberian kredit pada sektor ekonomi.

\section{Kebijaksanaan Pemberian Dan Pengawasan Kredit}

Pengawasan yang dilakukan oleh PT. BPR Jorong Kampung Tangah Pariaman merupakan hal yang penting dalam usaha perbankan. Tujuan dari pengawasan pemberian kredit ini untuk menjaga, mengamankan dan mengantisipasi terjadinya penyimpangan yang dapat menjadikan kredit bermasalah dan jika tidak ditindaklanjuti akan menyebabkan kerugian bagi Bank. Serta dengan adanya sistem ini, pihak Bank dapat mengetahui dengan cepat munculnya potensi kredit bermasalah yang dapat merugikan Bank.

Adapun pengawasan kredit yang dilakukan PT. BPR Jorong Kampung Tangah Pariaman dengan pengawasan kredit dengan cara :

1. Control by Exception

Hal yang bersifat exception dapat diketahui dengan kekuatan, kelemahan, kesempatan, dan ancaman (analisa SWOT), sehingga dengan demikian sasaran dan intensitas pengawasan difokuskan pada hal-hal yang lemah (faktor-faktor intern) dan hal-hal yang menjadi ancaman / membahayakan (faktor ekstern).

2. Pengawasan Fisik

Yaitu pengawasan yang langsung dilakukan ketempat usaha nasabah

3. Monitoring Perkreditan

BPR harus mengumpulkan data-data dan informasi baik informasi ekstern maupun informasi intern.

\section{KESIMPULAN}

Sebagaimana sebelumnya penulis telah membahas penilitiannya melalui bab per bab dan oleh karena itu penulis dapat menyimpulkan.

a. Didalam pemberian kredit PT. BPR Jorong Kampung Tangah Pariaman disalurkan melalui nasabah / debitur yang masih produktif dalam arti kata masih berpenghasilan yang tujuannya agar nasabah 
dapat membayar kembali kredit yang telah diberikan sesuai dengan syarat-syarat yang telah ditetapkan antara pihak bank dengan nasabah / debitur.

b. Dari struktur organisasi terlihat adanya pembagian tugas rangkap kepada beberapa bagian dan seksi, sehingga tidak terdapat pembatasan wewenang dan tanggung jawab yang jelas dari atasan kepada bawahan. Menurut penulis, hal ini akan mengganggu berjalannya pengendalian intern yang diharapkan diperusahaan.

c. PT. BPR Jorong Kampung Tangah Pariaman membagi jenis-jenis kredit yang diberikan kedalam beberapa bagian, antara lain :

1. Kredit Instalment

Kredit yang pembayaran cicilannya angsuran pokok ditambah angsuran bunga dimana bunga yang diberikan dengan sistem flat.

2. Kredit Reguler

Kredit yang pembayaran cicilannya angsuran bunga dibayar terlebih dahulu dengan menggunakan sistem sliding, sementara angsuran pokoknya dibayar setelah jatuh tempo pembayarannya.

d. Prosedur pemberian kredit di PT. BPR Jorong Kampung Tangah menunjukkan bagaimana langkah-langkah dari pemberian kredit yang diberikan terhadap nasabah yang ingin memperoleh kredit dengan jumlah yang dibatasi oleh PT. BPR Jorong Kampung Tangah.

e. Teknik Pengawasan Kredit, yang terdiri dari :

1. Control by Exception, hal yang bersifat exception dapat diketahui dengan kekuatan, kelemahan, kesempatan, dan ancaman. Sehingga dengan demikian sasaran dan intensitas pengawasan difokuskan pada hal-hal yang lemah, dan hal-hal yang menjadi ancaman .

2. Pengawasan Fisik, yaitu pengawasan yang langsung dilakukan ketempat usaha nasabah.

3. Monitoring Perkreditan, BPR harus mengumpulkan data-data dan informasi, baik informasi ekstern, maupun informasi intern.

\section{DAFTAR PUSTAKA}

Afriyeni, A. (2019). Mekanisme Transaksi Dan Sistem Perhitungan Bunga Kredit Usaha Mikro Kecil Dan Menengah (UMKM) Pada PT. Pegadaian (Persero) Cabang Ulak Karang. https://doi.org/10.17605/OSF.IO/WB2E6

Alanshari, F., \& Marlius, D. (2018). Prosedur Pemberian Kredit KPR Pada PT. Bank Tabungan Negara (Persero) TBK Cabang Pembantu Bukittinggi. https://doi.org/10.31227/osf.io/rsfhc

Amelia, L., \& Marlius, D. (2018). Pengendalian Kredit Dalam Upaya Menciptakan Bank Yang Sehat Pada PT. Bank Pembangunan Daerah Sumatera Barat Cabang Utama Padang. https://doi.org/10.31227/osf.io/kpc64 
Andriani, B., \& Susanto, R. (2019). Pengawasan Kredit PT. Bank Perkreditan Rakyat (BPR) Ophir Pasaman Barat. https://doi.org/10.31219/osf.io/aunvc

Darmawanto, \& Fernos, J. (2019). Prosedur Pemberian Kredit Pada Bank Nagari Cabang Sijunjung. https://doi.org/10.31227/osf.io/psqfy

Firmansyah, A., \& Fernos, J. (2019). Analisis Kredit Bermasalah Dilihat Dari Standar Non Performing Loan (NPL) Pada PT. Bank Perkreditan Rakyat (BPR) Prima Mulia Anugrah Cabang Padang. https://doi.org/10.31227/osf.io/gcj94

Ikbal, M., \& Marlius, D. (2017). Pengaruh Jumlah Taksiran Dan Uang Pinjaman Terhadap Laba Bersih Pada PT. Pegadaian (UPC) Gurun Laweh. https://doi.org/10.31227/osf.io/uch4a

Orlando, A., \& Susanto, R. (2019). Mekanisme Pencairan Kredit Usaha Rakyat Pada PT. Bank Rakyat Indonesia Unit Lubuk Buaya. https://doi.org/10.31219/osf.io/zuv2y

Pratama, D., \& Fernos, J. (2019). Prosedur Pelaksanaan Kredit Usaha Rakyat (KUR) Pada PT. Bank Nagari Cabang Padang. https://doi.org/10.31227/osf.io/ag68j

R., \& Afriyeni, A. (2019). Mekanisme Transaksi Dan Sistem Perhitungan Bunga Kredit Usaha Mikro Kecil Dan Menengah (UMKM) Pada PT. Pegadaian (Persero) Cabang Ulak Karang. https://doi.org/10.31219/osf.io/rqneu

R. Rapto Adi Nugroho. Perbankan Masalah Perkreditan. Jakarta : Prandya Paramita. Oktober 1978.

Sinungun, Muchdarsyah Drs. Manajemen Dana Bank. Jakarta : Rineka Cipta. Jakarta. April 1989.

Tri Cahyono, Bambang. Manajemen Perkreditan. Yogyakarta : Ananda. Juni 1983.

Tje'Aman, Edy Putra, SH. Kredit Perbankan. Yogyakarta : Liberty. Juli 1989.

Widayati, R. (2019). Pelaksanaan Prinsip Kehati-Hatian Dalam Pemberian Kredit Konsumtif Pada Bank Nagari Cabang Siteba. https://doi.org/10.17605/OSF.IO/FZVXR 
Widayati, R. (2019). Aktivitas Pemberian Kredit Komersil Pada Bank Nagari Cabang Sijunjung. https://doi.org/10.17605/OSF.IO/QTVZ9

Widayati, R. (2019). Pelaksanaan Kredit Pada Bank Perkreditan Rakyat LPN Pasar Baru Durian Sawahlunto. https://doi.org/10.17605/OSF.IO/5HPAB

Widayati, R. (2019). Aktivitas Pemberian Kredit Usaha Pada PT. Bank Perkreditan Rakyat Batang Kapas. https://doi.org/10.17605/OSF.IO/EDPN4

Yasman, R., \& Afriyeni, A. (2019). Prosedur Pemberian Kredit Pada PT. Bank Pekreditan Rakyat (BPR) Jorong Kampung Tangah (JKT) Pariaman Cabang Padang. https://doi.org/10.31219/osf.io/c5ufr 